\title{
LIPID METABOLISM IN THE NORTHERN PIKE (ESOX LUCIUS L.)-3. IN VIVO INCORPORATION OF 1-14C-ACETATE IN THE LIPIDS
}

\author{
J. H. F. M. KLUYTMANS and D. I. ZANDEE \\ Laboratory of Chemical Animal Physiology, State University, \\ 40 Jan van Galenstraat, Utrecht, The Netherlands
}

(Received 13 August 1973)

\begin{abstract}
The specific radioactivity of the total lipids isolated from different organs of the northern pike (Esox lucius L.) after injection of $\mathrm{Na}-1-{ }^{14} \mathrm{C}$-acetate showed the highest values in the liver and the gills.

2. In the liver, radioactivity was found mainly in the fatty acids, while in the gills the greater part was present in the unsaponifiable lipids.

3. The percentage incorporation of radioactivity in lipid classes did not change significantly from 2 to $24 \mathrm{hr}$ after injection, but decreased in phospholipids and increased in triglycerides during shorter incubation times.

4. The number of fatty acids labeled as well as the amount of radioactivity incorporated increased rapidly after $1{ }^{14} \mathrm{C}$-acetate injection. Virtually all fatty acids were labeled after $2 \mathrm{hr}$ injection.
\end{abstract}

\section{INTRODUCTION}

While many data are available on the fatty acid and lipid composition of fishes (Gruger et al., 1964; Lovern, 1964; Ackman, 1967; Malins \& Wekell, 1969) much less is known about the biosynthesis of lipids in these animals. Kayama \& Tsuchiya (1965) found that acetate could be incorporated into sterols and other lipids. Blondin et al. (1966) investigated the biosynthesis of sterols in a fresh-water teleost and showed that $2-{ }^{14} \mathrm{C}$-mevalonic acid was incorporated into squalene, lanosterol and cholesterol in a pathway probably identical to that of mammals.

Mead et al. (1960) investigated the incorporation of $1{ }^{14} \mathrm{C}$-acetate into fish fatty acids and found that acetate could be used in the conversion of linoleic acid to arachidonic acid.

Kayama et al. (1963) showed that $1-^{14} \mathrm{C}$-linoleic acid is a precursor of eicosapentaenoic and docosahexaenoic acids. Knipprath \& Mead (1968) injected goldfish with $1-{ }^{14} \mathrm{C}$-acetate and determined the radioactivity in a number of fatty acids in relation to the environmental temperature.

The highest activities they observed were present in palmitic and oleic acid.

The present studies show that acetate is a precursor in the de novo fatty acid synthesis as well as in the chain elongation of dietary or endogenous fatty acids. 
As we were interested in the relative rates of incorporation of acetate in fatty acids and unsaponifiable lipids and in the appearance of the labeled products in the different lipid classes and in the way these labeling patterns changed with time, a number of fishes were injected with $1-{ }^{14} \mathrm{C}$-acetate.

After various incubation times the distribution of the radioactivity of the total lipids from different tissues and from the lipid classes and the fatty acids was studied.

\section{MATERIALS AND METHODS}

The animals used in these studies were caught by net in the Maarseveense Plassen near Utrecht. Their estimated age was 2-3 years, with body weights varying from 300 to $600 \mathrm{~g}$.

In the laboratory they were kept at a temperature of about $12^{\circ} \mathrm{C}$ in aquaria with $\mathrm{Cu}$-free water, which was continuously aerated.

At the start of an experiment the animals were injected with 2 vol. of $50 \mu \mathrm{l}$ of a solution of $\mathrm{Na}-1-{ }^{14} \mathrm{C}$-acetate in water (New England Nuclear; sp. act. $40 \mathrm{mCi} / \mathrm{mM}$ ) in the right and left halves of the epiaxial muscles.

The dose administered was $1 \mu \mathrm{Ci} / \mathrm{g}$ wet wt. After the appropriate incubation times the animals were killed by decapitation.

The organs to be investigated were immediately removed and the lipids in these tissues and the remaining fraction extracted according to Folch et al. (1957). The unsaponifiable lipids and the fatty acids were isolated as described previously (Kluytmans \& Zandee, 1973). Aliquots of the total lipids were separated on thin-layer plates $(0.25 \mathrm{~mm}$ silica gel DO) as described by Skipsky et al. (1968).

In the experiments with a $24 \mathrm{hr}$ incubation time the amount of $1-{ }^{14} \mathrm{C}$-acetate oxidized was measured by trapping ${ }^{14} \mathrm{CO}_{2}$ as described by Jeffay \& Alvarez (1961).

The radioactivities of the isolated lipids were determined in scintillation liquid according to Hayes et al. (1956) with a Packard liquid scintillation spectrometer Model 2420. The radioactivity of the individual fatty acids was determined after separation of the fatty acid mixtures by semi-preparative gas-liquid chromatography by counting the glass beads (dia. $0.15 \mathrm{~mm}$ ) on which they were trapped. Corrections were made for ${ }^{40} \mathrm{~K}$ activity of the beads.

\section{RESULTS AND DISCUSSION}

\section{a. Oxidation and incorporation of injected $1-{ }^{14} \mathrm{C}$-acetate}

In two experiments in which the animals were killed after a $24 \mathrm{hr}$ incubation period, the fractions of injected $\mathrm{Na}-1-{ }^{14} \mathrm{C}$-acetate that were oxidized and incorporated in lipids were determined.

The results (Table 1) show that, although the amount of acetate oxidized was much higher in the animal with the lowest total lipid content, the incorporation in lipids was about the same, indicating that the basal activities of their lipid synthesizing systems are fairly independent of the level of starvation.

The amount of radioactivity not accounted for was probably still largely present as acetate, as Table 2 shows a steady increase in both the specific and total radioactivities incorporated in the lipids of all investigated tissues up to the longest incubation time of $24 \mathrm{hr}$. This acetate may have been bound to the proteins, whose radioactivity was not determined, or may have been lost during the extraction 
Table 1-Metabolic processing of intramuscular inJected $1-{ }^{14} \mathrm{C}$-Acetate

( $1 \mu \mathrm{Ci} / \mathrm{g}$ wet wt, specific activity $40 \mathrm{mCi} / \mathrm{mM}$ ) IN $24 \mathrm{hr}$ IN THE PIKE $\dagger$

\begin{tabular}{lcc}
\hline & Experiment 1 & Experiment 2 \\
\hline Weight (g) & 300 & 400 \\
Sex & Male & Female \\
Total lipids in the liver (\%) & $5 \cdot 8^{*}$ & $2 \cdot 4^{*}$ \\
Total lipids in the remainder (\%) & $1 \cdot 1^{*}$ & $0 \cdot 5^{*}$ \\
& $32 \cdot 3$ & $59 \cdot 5$ \\
Oxidized to $\mathrm{CO}_{2}(\%)$ & $4 \cdot 5$ & $5 \cdot 1$ \\
Incorporated in lipids (\%) & $3 \cdot 4$ & $2 \cdot 5$ \\
Incorporated in water-soluble materials (\%) & $59 \cdot 8$ & $32 \cdot 9$ \\
Incorporated in other materials or not in- & & \\
$\quad$ corporated (\%) & & \\
\hline
\end{tabular}

* Percentage of the wet weight.

$\uparrow$ The animals were starved for 2 months.

TABLE 2-RAdioactivity $\dagger$ IN THE TOTAL LIPIDS OF VARIOUS TISSUES AT DIFFERENT TIMES AFTER INJECTION OF $1 \mu \mathrm{Ci} 1-{ }^{14} \mathrm{C}$-ACETATE per $g$ wet $w t$

\begin{tabular}{lcccc}
\hline & Experiment 1 & Experiment 2 & Experiment 3 & Experiment 4 \\
\hline Weight (g) & 300 & 450 & 340 & 400 \\
Sex & Male & Female & Male & Female \\
Total lipids (\%) & $0 \cdot 65^{*}$ & $0 \cdot 95^{*}$ & $0 \cdot 60^{*}$ & $0 \cdot 75^{*}$ \\
Incubation time (hr) & 2 & 6 & 12 & 24 \\
& & & & \\
Muscle & 1900 & 4400 & 5400 & 6200 \\
Liver & 10,400 & 30,200 & 41,100 & 90,800 \\
Intestine & 3000 & 9700 & 12,600 & 19,300 \\
Gills & 12,300 & 13,100 & 45,800 & 58,500 \\
Spleen & 2800 & 14,300 & - & 14,700 \\
Testis & 2200 & - & 8600 & - \\
Ovaries & - & 1200 & - & 2900 \\
Remainder & 3600 & 14,900 & 15,700 & 27,200 \\
\hline
\end{tabular}

* Percentage of the wet weight of the whole animal.

$\uparrow$ The results are expressed in $\mathrm{dis} / \mathrm{min}$ per $\mathrm{mg}$.

procedure. The fact that acetate was injected into the dorsal white muscles, which normally receive only a very limited blood supply and have a low oxidative metabolism, probably has contributed to this observation, as this will result in a slow release of acetate via the blood to more active metabolizing tissues.

While all tissues show an increase in specific activity of the lipids, this was most obvious in the liver and in the gills. 
As the liver plays a prominent role in the synthesis of fatty acids and lipids and also is a lipid storage organ in fishes, these results were not unexpected.

However, as the level of fatty acid synthesis (unpublished results) and probably of other lipid components in the gills is very low, it seems likely that the radioactive lipids present in this tissue were withdrawn from the bloodstream. Saponification of the total lipids obtained from the gills showed that most of the radioactivity was present in the unsaponifiable fraction (Table 3).

TABLE 3-RADIOACTIVITY IN SAPONIFIABLE AND UNSAPONIFIABLE LIPIDS FROM VARIOUS TISSUES OF THE PIKE AFTER INTRAMUSCULAR INJECTION OF $1-{ }^{14} \mathrm{C}$-ACETATE $(1 \mu \mathrm{Ci} / \mathrm{g}$ wet wt, specific activity $40 \mathrm{mCi} / \mathrm{mM}$ )

\begin{tabular}{|c|c|c|c|c|c|c|c|c|}
\hline & \multicolumn{4}{|c|}{ Experiment 1} & \multicolumn{4}{|c|}{ Experiment 2} \\
\hline \multirow[t]{2}{*}{$\begin{array}{l}\text { Weight (g) } \\
\text { Sex* } \\
\text { Total lipids (\%) } \\
\text { Incubation time (hr) } \\
\text { Time of the year }\end{array}$} & \multicolumn{4}{|c|}{$\begin{array}{c}290 \\
\text { Male } \\
3 \cdot 5 \dagger \\
2 \\
\text { December }\end{array}$} & & $\begin{array}{r}40 \\
\mathrm{M} \\
4 \cdot ? \\
6 \\
\mathrm{Ma}\end{array}$ & $\begin{array}{l}0 \\
\text { le } \\
+ \\
\mathrm{rch}\end{array}$ & \\
\hline & $\begin{array}{r}\text { Unsa } \\
1\end{array}$ & $\begin{array}{l}\text { ponifiable } \\
\text { ipids }\end{array}$ & & $\begin{array}{l}\text { atty } \\
\text { iids }\end{array}$ & Unsay & $\begin{array}{l}\text { onifiable } \\
\text { pids }\end{array}$ & & $\begin{array}{l}\text { atty } \\
\text { cids }\end{array}$ \\
\hline \multirow[t]{2}{*}{$\begin{array}{l}\text { Total dis } / \min \times 10^{3} \\
\text { Percentage }\end{array}$} & \multicolumn{2}{|c|}{$\begin{array}{l}350 \\
4 \cdot 5\end{array}$} & \multicolumn{2}{|c|}{$\begin{array}{c}8,200 \\
95 \cdot 5\end{array}$} & \multicolumn{2}{|c|}{$\begin{array}{c}1,040 \\
7 \cdot 5\end{array}$} & \multicolumn{2}{|c|}{$\begin{array}{c}13,800 \\
92 \cdot 5\end{array}$} \\
\hline & $\mathrm{mg}$ & $\begin{array}{l}\mathrm{dis} / \mathrm{min} \\
\text { per } \mathrm{mg}\end{array}$ & $\mathrm{mg}$ & $\begin{array}{l}\mathrm{dis} / \mathrm{min} \\
\text { per } \mathrm{mg}\end{array}$ & $\mathrm{mg}$ & $\begin{array}{l}\mathrm{dis} / \mathrm{min} \\
\text { per } \mathrm{mg}\end{array}$ & $\mathrm{mg}$ & $\begin{array}{l}\text { dis } / \mathrm{min} \\
\text { per } \mathrm{mg}\end{array}$ \\
\hline Remainder & 233 & 880 & $5 \cdot 598$ & 923 & 179 & $1 \cdot 346$ & $7 \cdot 412$ & $1 \cdot 028$ \\
\hline Muscle & 115 & 329 & 363 & $3 \cdot 380$ & 271 & $1 \cdot 030$ & 424 & $2 \cdot 730$ \\
\hline Liver & 90 & 507 & 326 & $7 \cdot 650$ & 91 & 1.900 & 757 & $5 \cdot 550$ \\
\hline Gills & 65 & $2 \cdot 452$ & 6 & $7 \cdot 010$ & 25 & $13 \cdot 800$ & 14 & 5.890 \\
\hline Intestine & 11 & 204 & 173 & $1 \cdot 030$ & 35 & $1 \cdot 400$ & 112 & $10 \cdot 790$ \\
\hline Testis & 15 & 539 & 4 & 640 & 11 & $6 \cdot 720$ & 2 & $29 \cdot 090$ \\
\hline
\end{tabular}

* Animals were fed twice a week.

$\uparrow$ Percentage of wet weight.

This indicates an important role for one or more of the lipids in this fraction in the functioning of the gills, which deserves further investigation.

\section{b. Labeling of lipid classes}

The total lipids of the remaining fraction of animals incubated during different times after injection of $1{ }^{14} \mathrm{C}$-acetate were separated on thin-layer plates and the results obtained are presented in Table 4.

From 2 to $24 \mathrm{hr}$ there is no significant change in the percentage incorporation of radioactive acetate in the different lipid classes. 
TABLE 4-THE PERCENTAGE RADIOACTIVITY DISTRIBUTION OVER THE LIPID CLASSES ISOLATED FROM THE REMAINING FRACTION OF ANIMALS STARVED FOR 2 MONTHS AT DIFFERENT TIMES AFTER INJECTION OF $1 .{ }^{14} \mathrm{C}$-acetate $(1 \mu \mathrm{Ci} / \mathrm{g}$ wet wt specific activity $40 \mathrm{mCi} / \mathrm{mM})$

\begin{tabular}{|c|c|c|c|c|c|c|}
\hline & $\begin{array}{l}\text { Experi- } \\
\text { ment } 1\end{array}$ & $\begin{array}{l}\text { Experi- } \\
\text { ment } 2\end{array}$ & $\begin{array}{l}\text { Experi- } \\
\text { ment } 3\end{array}$ & $\begin{array}{l}\text { Experi- } \\
\text { ment } 4\end{array}$ & $\begin{array}{l}\text { Experi- } \\
\text { ment } 5\end{array}$ & \\
\hline Weight (g) & 300 & 450 & 340 & 400 & 300 & \\
\hline Sex & Male & Female & Male & Female & Male & \\
\hline Total lipids (\%) & $0.5 *$ & $0 \cdot 6^{*}$ & $0 \cdot 5^{*}$ & $0.5 *$ & $1 \cdot 0^{*}$ & \\
\hline Determinations & 3 & 3 & 2 & 4 & 3 & \\
\hline \multirow[t]{2}{*}{ Incubation time (hr) } & 2 & 6 & 12 & 24 & 24 & \\
\hline & & & & & & $\begin{array}{l}\text { Mean value } \\
\text { and standard } \\
\text { deviation }\end{array}$ \\
\hline Phospholipids & $50 \cdot 5$ & $61 \cdot 4$ & $57 \cdot 8$ & $56 \cdot 3$ & $54 \cdot 2$ & $55 \cdot 8 \pm 1 \cdot 8$ \\
\hline Monoglycerides & $4 \cdot 0$ & $4 \cdot 4$ & $3 \cdot 2$ & $3 \cdot 4$ & $2 \cdot 8$ & $3.6 \pm 0.3$ \\
\hline Cholesterol & 0.8 & $1 \cdot 0$ & 0.5 & $1 \cdot 5$ & $1 \cdot 3$ & $1 \cdot 2 \pm 0.2$ \\
\hline Diglycerides & $4 \cdot 4$ & $5 \cdot 3$ & $4 \cdot 0$ & $4 \cdot 8$ & $4 \cdot 2$ & $4 \cdot 3 \pm 0 \cdot 3$ \\
\hline $\begin{array}{l}\text { Free fatty acids and } \\
\text { triglycerides }\end{array}$ & $35 \cdot 5$ & $27 \cdot 1$ & $33 \cdot 6$ & $33 \cdot 1$ & $38 \cdot 7$ & $33 \cdot 6 \pm 2 \cdot 0$ \\
\hline Cholesterol esters & 0.6 & 0.4 & $0 \cdot 4$ & 0.6 & $0 \cdot 4$ & $0.5 \pm 0.1$ \\
\hline Hydrocarbons & - & 0.2 & $0 \cdot 3$ & $0 \cdot 2$ & - & $0.2 \pm 0.1$ \\
\hline
\end{tabular}

* Percentage of wet weight.

Within $2 \mathrm{hr}$ a dynamic equilibrium seems to have been reached, which, although the absolute radioactivity increases, maintains a fixed proportionality in the activity in the different lipid classes.

As the ratio of the radioactivity in the lipid classes did not change with the incubation time, the mean values and the standard deviations for the percentage radioactivity distribution were calculated (Table 4).

These figures are helpful in providing some indirect evidence about the role of the different lipid classes in lipid biosynthesis. When these values are divided by the percentage weight composition for the same lipid classes, the ratios represent the average specific activities, which are given in Table 5.

The highest value is found in the diglycerides, followed by the triglycerides and phospholipids, in agreement with the operation of the glycerol-3-phosphate pathway (Kornberg \& Pricer, 1952) in these fishes. The high specific activity in the monoglycerides is not easy to explain, but may have been caused by degradation of diglycerides.

To obtain more direct evidence about the pathways according to which lipids were synthesized, the labeling of lipid classes from the liver and remaining fraction was investigated after shorter incubation times (Table 6).

Both tissues show a definite decrease of the percentage radioactivity incorporation in the phospholipids and a corresponding increase in the triglycerides and the 
TABLE 5-RATIO OF THE SPECIFIC ACTIVITIES OF THE DIFFERENT LIPID CLASSES AS CALCULATED FROM THE AVERAGE PERCENTAGE ACTIVITY AND THE AVERAGE PERCENTAGE WEIGHT COMPOSITION

\begin{tabular}{lccc}
\hline & $\begin{array}{c}\text { Average } \\
\text { percentage } \\
\text { activity* }\end{array}$ & $\begin{array}{c}\text { Average } \\
\text { percentage } \\
\text { weight } \\
\text { compositiont }\end{array}$ & Ratio \\
\hline Phospholipids & $55 \cdot 8$ & $50 \cdot 6$ & $1 \cdot 1$ \\
Monoglycerides & $3 \cdot 6$ & $3 \cdot 4$ & $1 \cdot 2$ \\
Cholesterol & $1 \cdot 1$ & $12 \cdot 7$ & $0 \cdot 1$ \\
$\begin{array}{l}\text { Diglycerides } \\
\text { Free fatty acids and } \\
\text { triglycerides }\end{array}$ & 43.5 & $2 \cdot 7$ & $1 \cdot 7$ \\
$\begin{array}{l}\text { Cholesterol esters } \\
\text { Hydrocarbons }\end{array}$ & 0.5 & 26.5 & $1 \cdot 3$ \\
\hline
\end{tabular}

* From the data presented in Table 4.

$\dagger$ Average from five animals.

Table 6-The Percentage Radioactivity Distribution in the Lipid Classes From the LIVER AND REMAINING FRACTION AFTER INJECTION OF 1 - ${ }^{14} \mathrm{C}$-ACETATE $(1 \mu \mathrm{Ci} / \mathrm{g})$

\begin{tabular}{|c|c|c|c|c|c|c|}
\hline & \multicolumn{3}{|c|}{ Remainder* } & \multicolumn{3}{|c|}{ Liver } \\
\hline & $\begin{array}{l}\text { Experi- } \\
\text { ment } 1\end{array}$ & $\begin{array}{l}\text { Experi- } \\
\text { ment } 2\end{array}$ & $\begin{array}{l}\text { Experi- } \\
\text { ment } 3\end{array}$ & $\begin{array}{l}\text { Experi- } \\
\text { ment } 1\end{array}$ & $\begin{array}{l}\text { Experi- } \\
\text { ment } 2\end{array}$ & $\begin{array}{l}\text { Experi- } \\
\text { ment } 3\end{array}$ \\
\hline Weight (g) & 600 & 410 & 830 & $10 \cdot 5$ & $8 \cdot 2$ & $12 \cdot 5$ \\
\hline Sex & Male & Female & Female & & & \\
\hline Total lipids $(\%) \dagger$ & 0.7 & 0.9 & 5 & 3 & 4 & 16 \\
\hline Incubation time (hr) & $0 \cdot 25$ & 0.50 & 1 & $0 \cdot 25$ & $0 \cdot 5$ & 1 \\
\hline Phospholipids & $57 \cdot 0$ & $56 \cdot 0$ & $31 \cdot 7$ & $75 \cdot 5$ & $48 \cdot 0$ & $23 \cdot 0$ \\
\hline Monoglycerides & $3 \cdot 5$ & $2 \cdot 0$ & $6 \cdot 0$ & $2 \cdot 1$ & - & $2 \cdot 3$ \\
\hline Cholesterol & $6 \cdot 0$ & $7 \cdot 5$ & $6 \cdot 0$ & 3.9 & $1 \cdot 0$ & $5 \cdot 6$ \\
\hline Diglycerides & $7 \cdot 0$ & $6 \cdot 0$ & $15 \cdot 7$ & $4 \cdot 4$ & $1 \cdot 0$ & 4.9 \\
\hline $\begin{array}{l}\text { Free fatty acids and } \\
\text { triglycerides }\end{array}$ & $21 \cdot 0$ & $22 \cdot 0$ & $36 \cdot 5$ & $10 \cdot 9$ & $40 \cdot 0$ & $45 \cdot 6$ \\
\hline Cholesterol esters & $0 \cdot 5$ & 0.5 & $1 \cdot 0$ & $0 \cdot 2$ & $1 \cdot 4$ & $1 \cdot 2$ \\
\hline Hydrocarbons & 0.4 & 0.5 & $1 \cdot 1$ & $0 \cdot 3$ & $1 \cdot 5$ & $1 \cdot 6$ \\
\hline
\end{tabular}

* Represents the whole animal minus the liver in experiment 1 and minus the liver and the ovaries in experiments 2 and 3.

$\dagger$ Percentage of wet weight.

diglycerides. The high initial activity of the phospholipids was probably caused by the formation of phosphatidic acid, which was subsequently converted to diglycerides and triglycerides in accordance with the Kornberg-Pricer pathway. 
To diminish the amount of acetate oxidized and to increase the incorporation in lipids, the animals used in the experiments shown in Table 6 were re-fed for at least 2 weeks.

This fact explains the differences in the percentage radioactivity distribution given in this table compared to the results presented in Table 4, which show a shift in acetate incorporation from structural lipids after starvation to storage lipids after re-feeding.

The difference in the amounts of total lipids in the animals used in these experiments does not seem to have had much influence, as the liver lipids of the animals used in experiments 1 and 2, which had roughly the same amounts of total lipids, nevertheless show a clear shift of acetate incorporation from phospholipids to triglycerides.

The observation that this shift in radioactivity distribution is found first in the liver and only after a longer time (Table 6) in the body lipids stresses the important role of the liver in lipid synthesis.

\section{c. Labeling of fatty acids}

In Table 7 the labeling of the fatty acids from the liver and remainder total lipids is given.

After 15 min most of the activity is found in the end-products of the de novo fatty acid synthesis, namely palmitic and myristic acid.

With increasing incubation times there is a corresponding increase in the number of fatty acids labeled and after $2 \mathrm{hr}$ virtually all fatty acids were radioactive. However, some caution is justified here, because as a result of the limited resolution of the preparative gas chromatographic column it was impossible to determine which isomers, shown to be present in each peak (Kluytmans \& Zandee, 1973), were labeled.

Although there are some fluctuations as a consequence of individual variations within animals, there is a clear decrease of the relative amount of radioactivity in palmitic and myristic acid and an increase in palmitoleic acid, oleic acid and to a lesser extent also in other fatty acids (except stearic acid) with time.

From these data it is clear that although the de novo synthesis is more active than chain elongation and desaturation processes, the pike can incorporate acetate via these latter pathways into many other fatty acids besides the direct products of fatty acid synthetase.

This fact does not exclude that, under normal dietary conditions, probably most of these fatty acids are obtained from the food, but it shows that the animal is able to synthesize these acids itself when necessary.

This fact may have contributed to the very similar fatty acid composition found for pike caught in Lake Balaton (Hungary) by Farkas \& Herodek (1967) with the fatty acid composition of the animals used in these experiments and also to the comparatively identical fatty acid spectra observed in fed and starved pike (Kluytmans \& Zandee, 1973). 


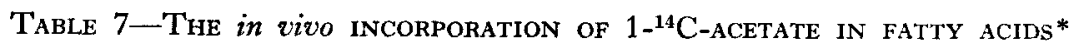
AFTER DIFFERENT INCUBATION TIMES

\begin{tabular}{|c|c|c|c|c|c|c|c|c|c|c|}
\hline & \multicolumn{2}{|c|}{ Experiment 1} & \multicolumn{2}{|c|}{ Experiment 2} & \multicolumn{2}{|c|}{ Experiment 3} & \multicolumn{2}{|c|}{ Experiment 4} & \multicolumn{2}{|c|}{ Experiment 5} \\
\hline Weight $(g)$ & \multicolumn{2}{|c|}{600} & \multicolumn{2}{|c|}{410} & \multicolumn{2}{|c|}{830} & \multicolumn{2}{|c|}{300} & \multicolumn{2}{|c|}{400} \\
\hline Sex & \multicolumn{2}{|c|}{ Male } & \multicolumn{2}{|c|}{ Female } & \multicolumn{2}{|c|}{ Female } & \multicolumn{2}{|c|}{ Male } & \multicolumn{2}{|c|}{ Female } \\
\hline $\begin{array}{l}\text { Incubation time } \\
(\mathrm{hr})\end{array}$ & \multicolumn{2}{|c|}{0.25} & \multicolumn{2}{|c|}{$0 \cdot 5$} & \multicolumn{2}{|c|}{1} & \multicolumn{2}{|c|}{2} & \multicolumn{2}{|c|}{6} \\
\hline Fraction & Rest & Liver & Rest & Liver & Rest & Liver & Rest & Liver & Rest & Liver \\
\hline Total lipids $\%$ & 0.7 & 3 & 0.9 & 4 & 3 & 16 & $3 \cdot 5$ & 7 & 6 & 20 \\
\hline $14: 0$ & $14 \cdot 2$ & $16 \cdot 9$ & $11 \cdot 0$ & $25 \cdot 6$ & $\begin{array}{l}0 \cdot 2 \dagger \\
5 \cdot 9\end{array}$ & $\begin{array}{l}0 \cdot 6 \dagger \\
16 \cdot 8\end{array}$ & $\begin{array}{l}0.4 \dagger \\
8.6\end{array}$ & $\begin{array}{l}0.1 \uparrow \\
6.8\end{array}$ & $\begin{array}{c}0 \cdot 5 \dagger \\
12 \cdot 2\end{array}$ & $\begin{array}{l}0.3 \dagger \\
8.8\end{array}$ \\
\hline $\left.\begin{array}{l}15: 0 \text { iso } \\
15: 0 \text { anteiso }\end{array}\right\}$ & & $0 \cdot 8$ & & & $0 \cdot 3$ & $0 \cdot 3$ & $0 \cdot 8$ & $0 \cdot 7$ & 0.9 & 0.4 \\
\hline $\begin{array}{l}15: 0 \\
15: 1\end{array}$ & & & & & & & $\begin{array}{l}0 \cdot 3 \\
0 \cdot 1\end{array}$ & $0 \cdot 1$ & $\begin{array}{l}0 \cdot 3 \\
0 \cdot 1\end{array}$ & $\begin{array}{l}0 \cdot 1 \\
0 \cdot 2\end{array}$ \\
\hline $16: 0$ iso & & & & & & & 0.4 & $0 \cdot 1$ & $0 \cdot 3$ & $0 \cdot 1$ \\
\hline $16: 0$ & $65 \cdot 5$ & $50 \cdot 6$ & $63 \cdot 8$ & $60 \cdot 8$ & $45 \cdot 5$ & $58 \cdot 3$ & $41 \cdot 5$ & $38 \cdot 4$ & $25 \cdot 3$ & $35 \cdot 0$ \\
\hline $16 \cdot 1$ & & $1 \cdot 8$ & 0.7 & $0 \cdot 2$ & $15 \cdot 2$ & $2 \cdot 6$ & $11 \cdot 6$ & $20 \cdot 5$ & $15 \cdot 1$ & $17 \cdot 1$ \\
\hline $\left.\begin{array}{l}17: 0 \text { iso } \\
17: 0 \text { anteiso }\end{array}\right\}$ & & $3 \cdot 5$ & 0.5 & $1 \cdot 3$ & 0.8 & $0 \cdot 3$ & $2 \cdot 6$ & $3 \cdot 5$ & $3 \cdot 2$ & $2 \cdot 9$ \\
\hline $\begin{array}{l}17: 0 \\
17: 1\end{array}$ & & & $0 \cdot 1$ & $0 \cdot 2$ & $0 \cdot 2$ & & $\begin{array}{l}1 \cdot 0 \\
1 \cdot 2\end{array}$ & $0 \cdot 6$ & $1 \cdot 8$ & $0 \cdot 7$ \\
\hline $18: 0$ iso & & & & & $0 \cdot 2$ & $0 \cdot 2$ & & $0 \cdot 2$ & $0 \cdot 7$ & $0 \cdot 4$ \\
\hline $18: 0$ & $16 \cdot 0$ & $12 \cdot 9$ & $15 \cdot 2$ & $9 \cdot 1$ & 14.9 & $13 \cdot 7$ & $11 \cdot 4$ & $9 \cdot 2$ & $12 \cdot 9^{-}$ & $12 \cdot 1$ \\
\hline $18: 1$ & 0.9 & 2.9 & $2 \cdot 0$ & $0 \cdot 7$ & 3.9 & $1 \cdot 1$ & $5 \cdot 6$ & $12 \cdot 1$ & $6 \cdot 3$ & $13 \cdot 5$ \\
\hline $18: 2$ & & 0.9 & & $0 \cdot 1$ & $1 \cdot 4$ & 0.9 & $0 \cdot 6$ & $3 \cdot 2$ & $0 \cdot 6$ & $7 \cdot 8$ \\
\hline $19: 1+18: 3 \phi 6$ & & $4 \cdot 1$ & $0 \cdot 4$ & $1 \cdot 1$ & $0 \cdot 5$ & & & $3 \cdot 8$ & $0 \cdot 4$ & $3 \cdot 9$ \\
\hline $18: 3 \phi 3$ & & & & & 0.8 & $0 \cdot 5$ & 0.5 & $0 \cdot 9$ & 0.4 & $0 \cdot 3$ \\
\hline $20: 0$ & & & $0 \cdot 2$ & & $0 \cdot 7$ & $0 \cdot 5$ & $0 \cdot 6$ & $0 \cdot 2$ & 0.7 & $0 \cdot 5$ \\
\hline $20: 1$ & & $1 \cdot 0$ & $1 \cdot 4$ & & 0.9 & $1 \cdot 0$ & $2 \cdot 5$ & $0 \cdot 2$ & 0.4 & $0 \cdot 6$ \\
\hline $19: 3 ?$ & & & & & & & & $0 \cdot 1$ & & $0 \cdot 4$ \\
\hline $20: 2\{$ & 0.5 & & $2 \cdot 5$ & & 0.8 & 0.7 & 0.8 & $0 \cdot 1$ & $1 \cdot 0$ & $0 \cdot 2$ \\
\hline $20: 3$ & & $0 \cdot 7$ & & 0.9 & & $0 \cdot 6$ & & $0 \cdot 1$ & & 0.2 \\
\hline $20: 4$ & & & $0 \cdot 2$ & & $0 \cdot 5$ & $2 \cdot 0$ & $0 \cdot 6$ & $0 \cdot 2$ & $1 \cdot 2$ & $0 \cdot 2$ \\
\hline $21: 3+22: 0$ & & & & & $0 \cdot 4$ & $1 \cdot 8$ & & $0 \cdot 1$ & $2 \cdot 0$ & $0 \cdot 3$ \\
\hline $20: 5$ & & & & & 0.5 & & & & $3 \cdot 2$ & \\
\hline $\begin{array}{l}\text { Rest } \\
\text { dis/min per mg } \\
\text { fatty acids }\end{array}$ & $\begin{array}{c}2 \cdot 9 \\
1,100\end{array}$ & 1,800 & $\begin{array}{c}2 \cdot 1 \\
3,900\end{array}$ & 2,500 & $\begin{array}{c}1 \cdot 3 \\
2,000\end{array}$ & $\begin{array}{r}4 \cdot 9 \\
520\end{array}$ & $\begin{array}{r}9 \cdot 1 \\
470\end{array}$ & $\begin{array}{c}4 \cdot 8 \\
3,600\end{array}$ & $\begin{array}{l}16 \cdot 4 \\
530\end{array}$ & $\begin{array}{c}3 \cdot 6 \\
1,900\end{array}$ \\
\hline
\end{tabular}

* Radioactivities of the individual components are given as percentages of the total radioactivity recovered after preparative gas chromatography.

† Fatty acids eluted before myristic acid. 
The rather complex fatty acid composition of the pike therefore may not be merely a reflection of the dietary fatty acids, but in view of the observed biosynthetic capabilities probably has some physiological and evolutionary significance, although on a biochemical level this has been only poorly investigated.

\section{REFERENCES}

ACKMAN R. G. (1967) Characteristics of the fatty acid composition and biochemistry of some fresh-water fish oils and lipids in comparison with marine oils and lipids. Comp. Biochem. Physiol. 22, 907-922.

Blondin G. A., ScotT J. L., Hummer J. K., Kulkarni B. D. \& Nes W. R. (1966) The biosynthesis of squalene and sterols in fish. Comp. Biochem. Physiol. 17, 391-407.

FARKAS T. \& HERODEK S. (1967) Investigations of the fatty acid composition of fishes from Lake Balaton. Anal. biol. Tihany 34, 3-13.

Folch J., LeEs M. \& Sloane Stanley G. H. (1957) A simple method for the isolation and the purification of total lipids from animal tissues. F. biol. Chem. 226, 497-509.

Gruger E. H., Nelson R. W. \& Stansby M. E. (1964) Fatty acid composition of oils from 21 species of marine fish, fresh-water fish and shellfish. f. Am. Oil chem. Soc. 41, 662-667.

Hayes F. N., Rogers B. S. \& Langham W. H. (1956) Counting suspensions in liquid scintillators. Nucleonics 14, 48-51.

JefFay H. \& Alvarez J. (1961) Liquid scintillation counting of carbon-14. Analyt. Chem. 33, 612-620.

KaYAMA M. \& TsUChIYA Y. (1965) Incorporation of $\mathrm{C}^{14}$-labeled acetate into lipid classes of liver oil by intact leopard shark. Tohoku F. agric. Res. 15, 259-267.

Kayama M., Tsuchiya Y., Nevenzel J. C., Fulco A. \& Mead J. F. (1963) Incorporation of linolenic-1-C $\mathrm{C}^{14}$ acid into eicosapentaenoic and docosahexaenoic acids in fish. $\mathcal{F}$. Am. Oil chem. Soc. 40, 499-502.

KLUYTMANS J. H. F. M. \& Z ZANDEE D. I. (1973) Lipid metabolism in the northern pike (Esox lucius L.)-1. The fatty acid composition of the northern pike. Comp. Biochem. Physiol. 44B, 451-458.

KNipPrath W. G. \& MEAD J. F. (1968) The effect of the environmental temperature on the fatty acid composition and on the in vivo incorporation of $1{ }^{14} \mathrm{C}$-acetate in goldfish (Carassius auratus L.). Lipids 3, 121-128.

Kornberg A. \& PRICER W. E. (1952) Enzymatic synthesis of phosphorus-containing lipids. f. Am. chem. Soc. 74, 1617.

LOVERN J. A. (1964) The lipids of marine organisms. Oceanogr. mar. biol. Ann. Rev. 2, 169-191.

Malins D. C. \& Wekell J. C. (1969) The lipid biochemistry of marine organisms. In Progress in the Chemistry of Fats and Other Lipids (Edited by Holman R. T.) Vol. 10, pp. 339-363. Pergamon Press, Oxford.

Mead J. F., Kayama M. \& Reiser R. (1960) Biogenesis of polyunsaturated acids in fish. F. Am. Oil chem. Soc. 37, 438-440.

SkIPSKY V. P., Good J. J., BARCLAY M. \& RegGio R. B. (1968) Quantitative analysis of simple lipid classes by thin-layer chromatography. Biochim. biophys. Acta 152, 10-19.

Key Word Index-Lipid metabolism; fatty acid metabolism; glyceride biosynthesis; $1-{ }^{14} \mathrm{C}$-acetate incorporation; pike; Esox lucius L. 